\title{
Serodiagnosis of Babesia equi in horses submitted to exercise stress ${ }^{1}$
}

\author{
Cristiane D. Baldani ${ }^{2}$, Rosangela Z. Machado²", Tânia F. Raso ${ }^{2}$ \\ and Aramis A. Pinto ${ }^{2}$
}

\begin{abstract}
Baldani C.D., Machado R.Z., Raso T.F. \& Pinto A.A. 2007. Serodiagnosis of Babesia equi in horses submitted to exercise stress. Pesquisa Veterinária Brasileira27(4):179-183. Departamento de Patologia Veterinária, Universidade Estadual Paulista, Faculdade de Ciências Agrárias e Veterinárias, Via de Acesso Prof. Paulo Donato Castellane s/n, Jaboticabal, SP 14870000, Brazil. E-mail: zacarias@fcav.unesp.br

A complement fixation test (CFT), performed in microtitre plates, based upon the use of crude antigenic preparation of Babesia equi was adapted for the detection of antibodies in serum of infected horses. The indirect fluorescent antibody test (IFAT) and enzyme-linked immunosorbent assay (ELISA) were also used for the immunodiagnosis of B. equi. Serum samples from 15 apparently healthy horses, previously conditioned to a high-speed equine treadmill, were taken before and after exercise. All the samples analyzed were positive for B. equi infection. There were no significant differences $(\mathrm{P}<0.01)$ between these 3 tests, or the condition of rest or stress. The combined use of CFT and IFAT or ELISA should be recommended in order to enable veterinary services to more efficiently prevent introduction of infected horses into disease-free areas.
\end{abstract}

INDEX TERMS: Babesia equi, diagnosis, complement fixation, indirect fluorescent antibody test, enzymelinked immunosorbent assay.

RESUMO.- [Diagnóstico sorológico de infestação por Babesia equi em eqüinos submetidos ao estresse do exercício.] A reação de fixação do complemento (RFC), realizada em microplacas, utilizando-se antígeno bruto de Babesia equi, foi adaptada para a deteç̧ão de anticorpos em soros de equïinos infectados. A reação de imunofluorescência indireta (RIFI) e o ensaio imunoenzimático (ELISA) também foram utilizados para o imunodiagnóstico de B. equi. Amostras de soro foram obtidas de 15 equiinos aparentemente sadios, submetidos a treinamento físico em esteira rolante de alto desempenho, sendo as amostras colhidas antes e após os exercícios. Todas as amostras testadas foram positivas para $B$. equi. Não houve diferença significativa $(P<0,01)$ entre estes 3 testes sorológicos, ou entre a condição de estresse e repouso. A combinação da RFC com a RIFI ou ELISA pode ser recomendada a fim

\footnotetext{
${ }^{1}$ Received on March 8, 2006.

Accepted for publication on December 18, 2006.

2 Departamento de Patologia Veterinária, Faculdade de Ciências Agrárias e Veterinárias, Universidade Estadual Paulista, Via de Acesso Prof. Paulo Donato Castellane s/n, Jaboticabal, SP 14870-000, Brazil. *Corresponding author: zacarias@fcav.unesp.br
}

de evitar a entrada de eqüinos portadores em áreas consideradas livres da doença.

TERMOS DE INDEXAÇÃO: Babesia equi, diagnóstico, reação de fixação do complemento, imunofluorescência indireta, ensaio imunoenzimático.

\section{INTRODUCTION}

Equine piroplasmosis or babesiosis is a tick-borne protozoal disease caused by two intraerythrocytic parasites, Babesia equi and Babesia caballi. This illness affects horses, mules, donkeys and zebras and may occur in acute, subacute or chronic form. The disease is characterized by fever, anemia, icterus, hepato and splenomegaly, intravascular hemolysis and petechial hemorrhages of the mucuous surfaces, and hemoglobinuria (Schein 1988).

Equine piroplasmosis has a worldwide distribution, being endemic in most tropical and subtropical areas of the world as well as in some temperate climatic zones (Schein 1988, De Waal 1992, Bruning 1996). Once infected horses become carriers of $B$. equi and potential disseminators of the parasite, the importation of horses into disease free-areas, such as Japan, Australia and North America, is only possible if they 
have been declared to be negative for piroplasmosis through serological testing (Bruning 1996). Therefore, serological tests have assumed a major role in international horse trade and there is indeed a great need for the development of a rapid, specific, sensitive, and inexpensive serological test.

The complement fixation test (CFT) was introduced as the official test for equine piroplasmosis by the United States Department of Agriculture (USDA) in 1969 and is now used worldwide as a recommendation of the Office International of Epizooties (OIE) for trade and regulatory testing purposes (Friedhoff 1982). Nevertheless, serological studies have shown the low sensitivity and specificity of the CFT in identifying equine piroplasmosis carriers, and while rarely giving false positives may result in a negative response in horses with latent infections (Weiland et al. 1986). The indirect fluorescent antibody test (IFAT) is also commonly used to detect specific antibodies to $B$. equi, especially in cases where the CFT has proved to be inconclusive (Bruning 1996). Although the IFAT is more sensitive than the CFT and rarely renders false negative results (Tenter \& Friedhoff 1986), standardization is difficult, considering the subjectivity of the reader in assessing the results (Bose 1995, Bruning 1996). Besides the CFT and IFAT, the enzyme-linked immunosorbent assay (ELISA) has also been used for the detection of Babesia infection and is nowadays an alternative for increased specificity and sensitive detection of acute and latent babesial infections.

Moreover, the effects of incremental exercises on the efficiency of the diagnosis of $B$. equi are aspects that should be considered. Horses submitted to training programs involving a large component of maximal exercise achieve a better degree of fitness and present marked increases in erythrocyte numbers, packed cell volume, haemoglobin concentration, total white cell count and lymphocytes (Smith et al. 1989). Another interesting feature is that the spleen is a great reservoir of Babesia parasites and it is known that the spleen of most mammals contracts during stress, being the effects of excitement or exercise most dramatic in horses (Smith et al. 1989).

The purpose of the present study was to perform a complement fixation test with a crude $B$. equi antigen prepared from a Brazilian strain and to evaluate the ability of this test comparatively with IFAT and ELISA for the detection of parasite carrier horses submitted to incremental exercises.

\section{MATERIALS AND METHODS}

\section{Babesia equi isolate}

A Babesia equi strain isolated from a foal of 8 days of birth at Faculdade de Ciências Agrárias e Veterinárias, Jaboticabal, Universidade Estadual Paulista, State of São Paulo, Brazil, was utilized in this study. The strain was maintained cryopreserved in $10 \%$ dimethyl sulphoxide.

\section{Antigen preparation}

For the preparation of $B$. equi antigen, a 2-year-old horse, free from hemoparasites, was splenectomized and inoculated intravenously with cryopreserved $B$. equi. The animal was monitored daily for the presence of parasites by microscopic examination of Giemsa stained blood smears. Infected blood was collected in an equal volume of Alsever's solution during the peak of parasitaemia, approximately $80 \%$, which occurred on the 9 th day after inoculation. Briefly, the blood was diluted $1: 4$ in normal saline and the infected erythrocytes subjected to lyses with ammonion chloride (Machado et al. 1994). $B$. equi free merozoites were disrupted by 9 freezing $\left(-0^{\circ} \mathrm{C}\right) /$ thawing cycles $\left(37^{\circ} \mathrm{C}\right)$, lyophilized and stored at $-70^{\circ} \mathrm{C}$ until required for the CFT and ELISA.

IFAT antigen was also prepared from blood of experimentally infected horse. The erythrocytes were washed 4 times in normal saline and after the last wash the packed red-blood cells were adjusted to obtain an ideal concentration of parasites, approximately 30 parasites per field of view. Blood smears were made onto previously cleaned glass slides, which were dried for 6 hours at room temperature, wrapped in aluminum foil with tissue paper separating each slide, and stored at $-70^{\circ} \mathrm{C}$.

\section{Serum samples}

Positive and negative reference sera were used to optimize the CFT test. Fifteen serum samples collected from foals before they suckled colostrum were used as reference negative control sera, while 15 sera samples positive for $B$. equi by IFAT and blood smear examination were used as positive control sera. Another batch of 15 sera samples tested positive for $B$. caballi by IFAT and negative for $B$. equi were used in this study. Sera from 15 Arabian apparently healthy horses of northeastern São Paulo State were also examined. These samples were collected before and after the horses were submitted to incremental exercises on the treadmill as determined by the exercise protocol described below.

\section{Exercise protocol}

Horses previously conditioned to a high-speed equine treadmill, were exercised under controlled conditions. Blood was taken while the animals were at rest, immediately prior to exercise-induced stress. Each horse was run at $4 \mathrm{~m} / \mathrm{s}$ for 5 minutes to warm up and was then exercised for 2 minutes at $6 \mathrm{~m} / \mathrm{s}, 8 \mathrm{~m} / \mathrm{s}$ and $10 \mathrm{~m} / \mathrm{s}$ on a 6 degree incline. Immediately after exercised to exhaustion, additional blood sample was aseptically collected from the jugular vein, allowed to clot, centrifuged at $2000 \mathrm{xg}$ for 10 minutes and stored at $-20^{\circ} \mathrm{C}$ until use.

\section{Complement fixation test (CFT)}

The method used was that described by Bier et al. (1968), which is based on a 50 per cent hemolytic unit and followed closely for the titration of complement, amboceptor and sheep erythrocyte. The exceptions is that the tests were performed in microtitre plates and all dilutions of reagents were made in an isotonic trietanolamina buffer (TEL) $\mathrm{pH} 7.4$, prepared with $100 \mathrm{~mL}$ of trietanolamina stock solution $\left(1.232 \mathrm{~g}\right.$ of $\mathrm{MgSO}_{4}$ $7 \mathrm{H}_{2} \mathrm{O}, 0.2 \mathrm{~g}$ of $\mathrm{CaCl}_{2} 2 \mathrm{H}_{2} \mathrm{O}, 75 \mathrm{~g} \mathrm{NaCl}, 28 \mathrm{~mL}$ of trietanolamina and $1,000 \mathrm{~mL}$ of distilled water) and $8.3 \mathrm{~mL}$ of a sterile solution of $1 \%$ gelatin, made up to exactly $1,000 \mathrm{~mL}$ of distilled water. 
In short, optimal dilution of the antigen suspension was determined in a two dimensional block titration against the standard anti-sera panel mentioned previously. For the titration of serum samples, the antigen was kept constant at the predetermined concentration and serum was added to the test in two fold dilutions from 1:5 to 1:1,280. All serum samples were inactivated at $56^{\circ} \mathrm{C}$ for 30 minutes before use. Each reagent, test serum and antigen (crude $B$. equi) was added in $25 \mu \mathrm{L}$ amounts. Two 50 per cent hemolytic units (2.0 CH50) of complement in a volume of $50 \mu \mathrm{L}$ were used in the tests, which were held 4 hours at $4-6^{\circ} \mathrm{C}$, followed by further incubation of 1 hour at $37^{\circ} \mathrm{C}$ to allow time for fixation. Thereafter, a volume of $25 \mu \mathrm{L}$ of sensitized sheep erythrocytes were added to each well and the mixtures were then incubated at $37^{\circ} \mathrm{C}$ for 45 minutes to allow time for hemolysis. The microplates were finally centrifuged at 200xg for 5 minutes and the degree of lysis was read with the aid of a standard lysis scale. The point of $50 \%$ hemolysis was determined by graphic interpolation. All the tests included negative and positive control sera, as well as appropriate complement and haemolytic control systems. Controls for anti-complementary effects of serum and antigen dilutions were also included in the test. The degree of lysis was scored as + (75\% lysis), ++ $(50 \%$ lysis $),+++(25 \%$ lysis $)$ or ++++ (nil lysis). Animals showing less than $50 \%$ lysis at serum dilution of $1: 5$ in the presence of 2 units of complement were deemed to be positive.

\section{Indirect fluorescent antibody test (IFAT)}

The IFAT procedure essentially followed those previously described (Callow et al. 1979). Briefly, antigen slides were incubated with test sera for 45 minutes, starting at 1:40 serum dilution with subsequent 2-fold serial dilution to establish end points. After washing with phosphate-buffered saline (PBS), they were incubated with FITIC-labelled anti-horse IgG (KPL, EUA) and examined under a fluorescent microscopy (Olympus, BX-FLA). Sera were considered positive if it showed strong fluorescence of the parasites at a dilution of $1: 80$ or above.

\section{Enzyme-linked immunosorbent assay (ELISA)}

ELISA was performed as described previously (Baldani et al. 2004). Ninety-six-well microtitration plates (Nunclon ${ }^{\mathrm{TM}}$ Surface; Nunc, Denmark) were coated overnight at $4^{\circ} \mathrm{C}$ with $100 \mu \mathrm{L}(10 \mu \mathrm{g} / \mathrm{mL})$ of crude B. equi antigen diluted in a sodium bicarbonate-carbonated $0.05 \mathrm{M}$ buffer $(\mathrm{pH} 9.6)$. Alkaline phosphatase conjugated anti-horse IgG (Sigma, EUA) was used $1: 30,000$. The immunological activity of each serum was calculated by determining the sample to positive serum ratio $(\mathrm{S} / \mathrm{P})$, considering positive and negative sera as reference. Horses were considered to be positive when $\mathrm{S} / \mathrm{P}$ values at an optical density of $405 \mathrm{hm}$ were equal or greater than 0.278 .

\section{Statistical analysis}

Statistical analysis of the results was performed using a Chi-square test, comparing positive rates obtained for $B$. equi by CFT, IFAT and ELISA, before and after strenuous exercise.

\section{RESULTS AND DISCUSSION}

The CFT outlined in this study combines ease of performance with the technical accuracy of the quantitative method in which fixation mixtures are set up with serial dilutions of serum, a maximally reactive dose of antigen and a fixed dose of complement. Moreover, the CFT described in this paper is based on the use of reference sera to clearly define the difference between negative and positive sera.

Checkerboard titration showed a antigen concentration of 1:40 in TEL buffer pH 7.4 as optimum. Serum samples were diluted at $1: 5$ to $1: 1,280$, in which the titers of the negative reference sera were $\leq 1: 5$. On the other hand, the titers observed for all the anti-Babesia equi reference sera were $\geq 1: 5$. This data gave a sensitivity of $100 \%$, demonstrating that the CFT based on the use of crude $B$. equi antigen clearly discriminates between positive and negative reference sera. This result differs from those reported by several other researchers which have demonstrated the low sensitivity of the CFT in the detection of antibodies anti-B. equi in naturally and experimentally infected horses (Tenter \& Friedhoff 1986, Weiland 1986). However, the anti- $B$. caballi sera group demonstrated to be positive by the CFT, being all the horse titers $\geq 1: 5$. Therefore, cross-reaction with $B$. caballi was observed and the specificity of the CFT presented in this paper was $50 \%$. Similar results were reported by Joyner et al. (1981) which attributed the finding of a disproportionately high number of $B$. equi positive animals in the United Kingdom to the cross-reaction of $B$. caballi positive sera with B. equi antigen.

Donelly et al. (1980) have also reported such cross-reaction in the CFT. This lack of specificity however is not very important since the objective of the test, especially for international trade of horses, is to detect animals infected with either one or both species of Babesia. It is so that only serologically negative horses for both babesia can enter disease free areas. Of more consequence would be the possible lack of sensitivity, which would result in failure to detect lowlevel carrier animals.

Antibody titers to crude B. equi antigen were determined by CFT, IFAT and ELISA in sera of 15 Arabian horses from the State of São Paulo, at rest and after strenuous exercise. The results indicate that there are no significant differences $(\mathrm{P}<0.01)$ between the three tests on the detection of parasite carriers, as well as in the condition of rest or stress, once all the horses were positive for $B$. equi. However, titers of some horses increased or decreased when under strenuous exercise in all serological tests (Table 1). This may be correlated to spleen contraction during stress, which probably results in a release of parasites from the spleen and could also be responsible for clinical manifestation of the disease in horses submitted to heavy exercise (Hailat et al. 1997). Thus, Wong et al. (1992) demonstrated that serum IgG, IgM and IgA values after exercise were not significantly different from those obtained before exercise, although the research was performed in horses not infected with $B$. equi. It is so that further studies on cellular and humoral immunological response should be carried out in order to elucidate such aspects on the infection of $B$. equi. 
Table 1. Detection of antibodies to Babesia equi in horses from the State of São Paulo, Brazil, before and after strenuous exercise by serodiagnostic methods with crude antigenic preparation

\begin{tabular}{cccccccc}
\hline \multirow{2}{*}{$\begin{array}{c}\text { Horse } \\
\text { no. }\end{array}$} & \multicolumn{3}{c}{ Before exercise } & & \multicolumn{3}{c}{ After exercise } \\
\cline { 2 - 5 } \cline { 6 - 8 } & CFT $^{\mathrm{a}}$ & IFAT $^{\mathrm{b}}$ & ELISA $^{\mathrm{C}}$ & & CFT $^{\mathrm{a}}$ & IFAT $^{\mathrm{b}}$ & ELISA $^{\mathrm{C}}$ \\
\hline 1 & $1: 20$ & $1: 320$ & 0.796 & & $1: 40$ & $1: 1,280$ & 0.986 \\
2 & $1: 20$ & $1: 1,280$ & 0.704 & & $1: 40$ & $1: 640$ & 0.840 \\
3 & $1: 20$ & $1: 640$ & 0.787 & & $1: 20$ & $1: 1,280$ & 0.767 \\
4 & $1: 80$ & $1: 1,280$ & 1.219 & & $1: 160$ & $1: 1,280$ & 1.658 \\
5 & $1: 80$ & $1: 320$ & 1.237 & & $1: 40$ & $1: 320$ & 1.110 \\
6 & $1: 40$ & $1: 640$ & 1.385 & & $1: 80$ & $1: 640$ & 1.400 \\
7 & $1: 40$ & $1: 160$ & 1.185 & & $1: 40$ & $1: 1,280$ & 1.061 \\
8 & $1: 320$ & $1: 1,280$ & 1.198 & & $1: 320$ & $1: 640$ & 1.230 \\
9 & $1: 40$ & $1: 160$ & 1.188 & & $1: 40$ & $1: 160$ & 0.918 \\
10 & $1: 40$ & $1: 1,280$ & 0.944 & & $1: 40$ & $1: 320$ & 0.865 \\
11 & $1: 80$ & $1: 320$ & 1.925 & & $1: 40$ & $1: 1,280$ & 1.900 \\
12 & $1: 80$ & $1: 320$ & 1.097 & & $1: 80$ & $1: 640$ & 0.954 \\
13 & $1: 40$ & $1: 640$ & 1.074 & & $1: 80$ & $1: 320$ & 1.121 \\
14 & $1: 80$ & $1: 160$ & 1.112 & & $1: 80$ & $1: 640$ & 0.845 \\
15 & $1: 40$ & $1: 160$ & 0.565 & & $1: 40$ & $1: 320$ & 0.516
\end{tabular}

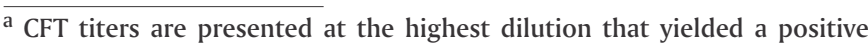
result $(\geq 1: 5)$;

b IFAT titers are presented at the highest dilution that yielded a positive result $(\leq 1: 80)$;

${ }^{c}$ ELISA was considered positive when an optical density at $405 \mathrm{hm}$ equal or greater than 0.278 was observed.

Although our results demonstrate no significant differences on positive rates for B. equi obtained by CFT, IFAT and ELISA, former studies have reported the excellent performance of IFAT as compared with the CFT on detection of antibodies to B. equi in the sera of infected horses (Tenter \& Friedhoff 1986; Weiland 1986). Additionally, various procedures of ELISA have been standardized and shown to be more sensitive and specific than CFT and IFAT (Knowles et al. 1991, Kumar et al. 2003). Therefore, the advantages and disadvantages of each test should be considered at the moment of choice of the best test for the diagnosis of equine piroplasmosis. It should be mentioned that the standardization of the ELISA was performed in a previous study, which demonstrated that the specificity and sensitivity of the test using a crude antigenic preparation of $B$. equi was $100 \%$ (Baldani et al. 2004), with the advantage of using very low concentration of the antigen $(10 \mu \mathrm{g} / \mathrm{mL})$ when compared to those reported by Kumar et al. (2003), which varied between $370 \mu \mathrm{g} / \mathrm{mL}$ and $500 \mu \mathrm{g} / \mathrm{mL}$. The IFAT, on the other hand, showed cross-reactions with $B$. caballi reference sera, although titers were not very high $(\leq 1: 80)$. Moreover, serum samples of known identity were deliberately selected from a previous study for the standardization of all tests to increase the confidence so that unknown field sera with different antibody titers could be evaluated perfectly.

The study of the humoral response in sera from Brazilian horses has shown that equine piroplasmosis is a serious problem in Brazil. Our results demonstrate a high prevalence for B. equi in northeastern São Paulo Stae and are in accordance with those published by Xuan et al. (2001) who recorded prevalence of $81 \%$ for B. equi. Heuchert et al. (1999) tested 752 serum samples from the State of São Paulo by IFAT and CFT and reported prevalence rates of $29.6 \%$ and $17.6 \%$, respectively. Moreover, serum samples from 90 horses of the same region of the present study were tested by ELISA and the prevalence of $B$. equi found was $75 \%$ (Baldani et al. 2004). The frequency of equine piroplasmosis recorded in this study is significantly higher than that recorded by Heuchert et al. (1999). This may be due to differences in management of the horses, which appears to be an important factor for the prevalence of $B$. equi infections and, to a lesser extent, to the number of serum samples examined. It has been demonstrated that where horses have direct or indirect contact with cattle and where there is no severe tick control program, the incidence of $B$. equi is much higher (Heuchert et al. 1999, Kerber et al. 1999).

Antigenic preparation in the present study was produced using a very simple methodology and required little material manipulation at a very low cost. Good crude antigenic preparations of intracellular parasites are difficult to produce, particularly due to the presence of host contaminant components, such as red blood fragments. These contaminants make the standardization of immunological assays a crucial step (Mahoney \& Goodger 1981) since they increase the occurrence of non-specific reactions. Zwart \& Broklesby (1979) suggest that the technique adopted for the preparation of Babesia antigen is crucial and has an important role on the specificity/cross-reactivity of the diagnosis test. Moreover, the limited offer of crude antigenic preparation is probably the major reason why recent research has been toward the development of serological tests that use recombinant antigens (Xuan et al. 2001). The advantages of recombinant antigen over native antigen are that standardization of the test is facilitated, it makes unnecessary the long-term in vitro cultivation of the parasites or the artificial infection of horses for antigen production, although the cost is relatively higher (Bruning 1996). It is probable that in the near future a sensitive and specific serological test using recombinant antigens will be used worldwide as a gold-standard test for the detection of $B$. equi parasite carriers.

In conclusion, we have provided convincing data which demonstrate the usefulness of the CFT using crude antigenic preparation for the detection of $B$. equi infection. Moreover, there is no difference in collecting blood samples before or after exercise for serological diagnosis of equine piroplasmosis. The combined use of CFT and IFAT or ELISA is recommended in order to enable veterinary services to prevent more efficiently introduction of infected horses into diseasefree areas, where the infections could become endemic.

Acknowledgements.- This study was supported by grants from Fundação de Amparo à Pesquisa do Estado de São Paulo (FAPESP, Proc.02/06126-1 and 02/13561-6).

\section{REFERENCES}

Baldani C.D., Machado R.Z., Botteon P.T.L., Takakura F.S. \& Massard C.L. 2004. An enzyme-linked immunosorbent assay for the detection of $\operatorname{IgG}$ antibodies against Babesia equi in horses. Ciência Rural, Santa Maria, 34(5):1525-1529.

Bier O., Siqueira M. \& Esteves M.B. 1968. Quantitative studies of complement 
fixation. I. A simplified and accurate procedure based on 50 per cent hemolytic en point. Revta Inst. Med. Trop. São Paulo 10(4):199-208.

Bose R., Jorgensen W.K., Dalgliesh R.J., Friedhoff K.T. \& De Vos A.J. 1995. Current state and future trends in the diagnosis of babesiosis. Vet. Parasitol. 57:61-74.

Bruning A. 1996. Equine piroplasmosis an update on diagnosis, treatment and prevention. Brit. Vet. J. 152:139-151.

Callow L.L., McGregor W., Rodwell B., Rogers R., Fraser G., Mahoney D. \& Robertson G. 1979. Evaluation of an indirect fluorescent antibody test to diagnose Babesia equi infections in horses. Aust. Vet. J. 55:555-559.

De Waal D.T. 1992. Equine piroplasmosis: a review. Brit. Vet. J. 148:6-14.

Donnelly J., Joyner L.P., Graham-Jones O. \& Ellis C.P. 1980. A comparison of the complement fixation and immunofluorescent antibody tests in a survey of the prevalence of Babesia equi and Babesia caballi in horses in the sultanate of Oman. Trop. Anim. Hlth Prod. 12:50-60.

Friedhoff K.T. 1982. Die piroplasmen der equiden - Bedeutung fur den internacionalen pferdeverkehr. Berl. Münch. Tierärztl. Wochenschr. 95:368374 .

Hailat N.Q., Lafi S.Q., Al-Darraji A.M. \& Al-Ani F.K. 1997. Equine babesiosis associated with strenuous exercise: clinical and pathological studies in Jordan. Vet. Parasitol. 69(1-2):1-8.

Heuchert C.M., Giulli Jr V., Athaide D.F., Bose R. \& Friedhoff K.T. 1999. Seroepidemiologic studies on Babesia equi and Babesia caballi infections in Brazil. Vet. Parasitol. 85(1):1-11.

Joyner L.P., Donnelly J. \& Huck R.A. 1981. Complement fixation tests for equine piroplasmosis (Babesia equi and B. caballi) performed in the UK during 1976 to 1979. Equine Vet. J. 13(2):103-106.

Kerber C.E., Ferreira F. \& Pereira M.C. 1999. Control of equine piroplasmosis in Brazil. Onderstepoort J. Vet. Res. 66(2):123-127.

Knowles D.P., Perryman L.E., Kappmeyer L.S. \& Hennager S.G. 1991. Detection of equine antibody to Babesia equi merozoite protein by a monoclonal antibody-based competitive inhibition enzyme-linked immunosorbent assay. J. Clin. Microbiol. 29:2056-2058.

Kumar S., Kumar Y., Malhotra D.V., Dhar S. \& Nichani A.K. 2003. Standardization and comparison of serial dilution and single dilution enzyme linked immunosorbent assay (ELISA) using different antigenic preparations of the Babesia (Theileria) equi parasite. Vet. Res. 34(1):71-83.

Machado R.Z., Valadão C.A.A., Melo W.R. \& Alessi A.C. 1994. Isolation of Babesia bigemina and Babesia bovis merozoites by ammonium chlorid lysis of infected erythrocytes. Braz. J. Med. Biol. Res. 27:2591-2598.

Mahoney D.F. \& Goodger B.V. 1981. The isolation of Babesia parasites and their products from the blood, p.323-332. In: Ristic M. \& Kreier J.P. (ed.), Babesiosis. Academic Press, New York.

Schein E. 1988. Equine babesiosis, p.197-208. In: Ristic M. (ed.), Babesiosis of Domestic Animals and Man. CRS Press, Boca Raton, Florida.

Smith J.E., Erickson H.H. \& Debowes R.M. 1989. Changes in circulating equine erythrocytes induced by brief, high-speed exercise. Equine Vet. J. 21(6):444446.

Tenter A.M. \& Friedhoff K.T. 1986. Serodiagnosis of experimental and natural Babesia equi and B. caballi infections. Vet. Parasitol. 20(1-3):49-61.

Weiland G. 1986. Species-specific serodiagnosis of equine piroplasma infections by means of complement fixation test (CFT), immunofluorescence (IF), and enzyme-linked immunosorbent assay (ELISA). Vet. Parasitol. 20(1-3):43-48.

Wong C.W., Smith S.E., Thong Y.H., Opdebeeck J.P. \& Thornton J.R. 1992. Effects of exercise stress on various immune functions in horses. Am. J. Vet. Res. 53(8):1414-1417

Xuan X., Nagai A., Battsetseg B., Fukumoto S., Makala L.H., Inoue N., Igarashi I., Mikami T. \& Kujisaki K. 2001. Diagnosis of equine piroplasmosis in Brazil by serodiagnostic methods with recombinant antigens. J. Vet. Med. Sci. 63(10):1159-1160.

Zwart D. \& Brocklesby D.W. 1979. Babesiosis: non-specific resistance, immunological factors and pathogenesis. Adv. Parasitol. 17:49-113. 